\title{
The Impact of Financial Leverage and CSR on the Corporate Value: Egyptian Case
}

\author{
Yasmeen Tarek $^{1}$ \\ ${ }^{1}$ Ph.D. (Finance), Faculty of Commerce, Suez Canal University, Egypt \\ ${ }^{2}$ Lecturer of Finance, Faculty of Management, MTI University, Cairo, Egypt \\ Correspondence: Yasmeen Tarek, Financial Institutions Department, MTI University, Cairo, Egypt. E-mail: \\ yasmeentghk@yahoo.com
}

Received: February 11, 2019

Accepted: March 11, 2019

Online Published: March 18, 2019

doi:10.5539/ijef.v11n4p74

URL: https://doi.org/10.5539/ijef.v11n4p74

\begin{abstract}
The study aimed to analyze the effect of the capital structure of the corporate and its interference in corporate social responsibility activities on the firms corporate value during the time period from 2014-2017 the study tested the effect of financial leverage and CSR on the corporate value of the firms by testing 17 companies registered in the indicator of CSR in the Egyptian stock market through applying panel data analysis. After testing the effect of both variables together the study found that there is significant effect of financial leverage on corporate value while applying CSR activities has no effect on the corporate values which means that there is a lack in the awareness of investors about the importance of applying CSR activities in Egypt.
\end{abstract}

Keywords: financial leverage, corporate social responsibility, corporate value, S\&P Egypt in the Egyptian stock market

\section{Introduction}

In the business research the main objective is to determine the factors that affect the corporate value which can be determined through examining firm CSR and its leverage which in turn will affect the corporate value of firms. It has been claimed by many researchers that financial leverage is considered as one of the most crucial factors that can affect the corporate's profitability as it can also affect firm corporate value. And this because the firm can get benefits from relying on debt as a part from its capital structure because payments of interest on debts are not taxable and that may lead to increasing firm value. And according to Brigham and Gapenski (1997) "The percentage of debt used by corporates in financing has three important implications: (1) By using debts in raising funds, stockholders can control a corporate with a limited investment. (2) Creditors look to the equity, to provide an edge of safety, so if the stockholders have provided only a small proportion of the total financing, the risks of the enterprise are carried mainly by its creditors. (3) If the earning of corporates are more on investments financed with borrowed funds than it pays in interest, the rate of return on owners' capital will be magnified, or leveraged, which means that the use of financial leverage is one of the aspects that may improve financial performance.

Another factor which is considered recently one of the aspects that may has effect on corporates performance and profitability is the CSR corporate social responsibility. CSR is the commitment of a business to act ethically, operate legally and participate in improving the economy, CSR can provide many benefits for the firms and communities. First, applying CSR can make the products of these firms considered by the society more attractive which will increase the profitability of firms and this will improve the financial performance. Second, it enhances the image of the companies which can be considered as a social marketing for the company.

There is an interaction between CSR and the financial leverage which in turn can affect the financial performance of firms as CSR reduces losses in market share when firms have degree of leverage and this is through minimizing the resisting attitude of customers and competitors. So the study aims to analyze the interaction between the firms' value and applying the activities of CSR and the financial leverage. The success in applying CSR activities can be considered as tool of what is called green finance which is an innovative financial design which aims to protect the environment and achieve the best utilization of resources. If the market mechanism of green finance is reasonable, green finance can guide the flow of funds and achieve effective 
management of environmental risk and optimal allocation of environmental and social resources.

\subsection{Literature Review}

There are previous studies related to the relationship between financial leverage, corporate social responsibility and the firm's corporate value. There are many studies on this subject as well which provides theoretical arguments to show how CSR and financial leverage affect corporate value.

Table 1. Literature review

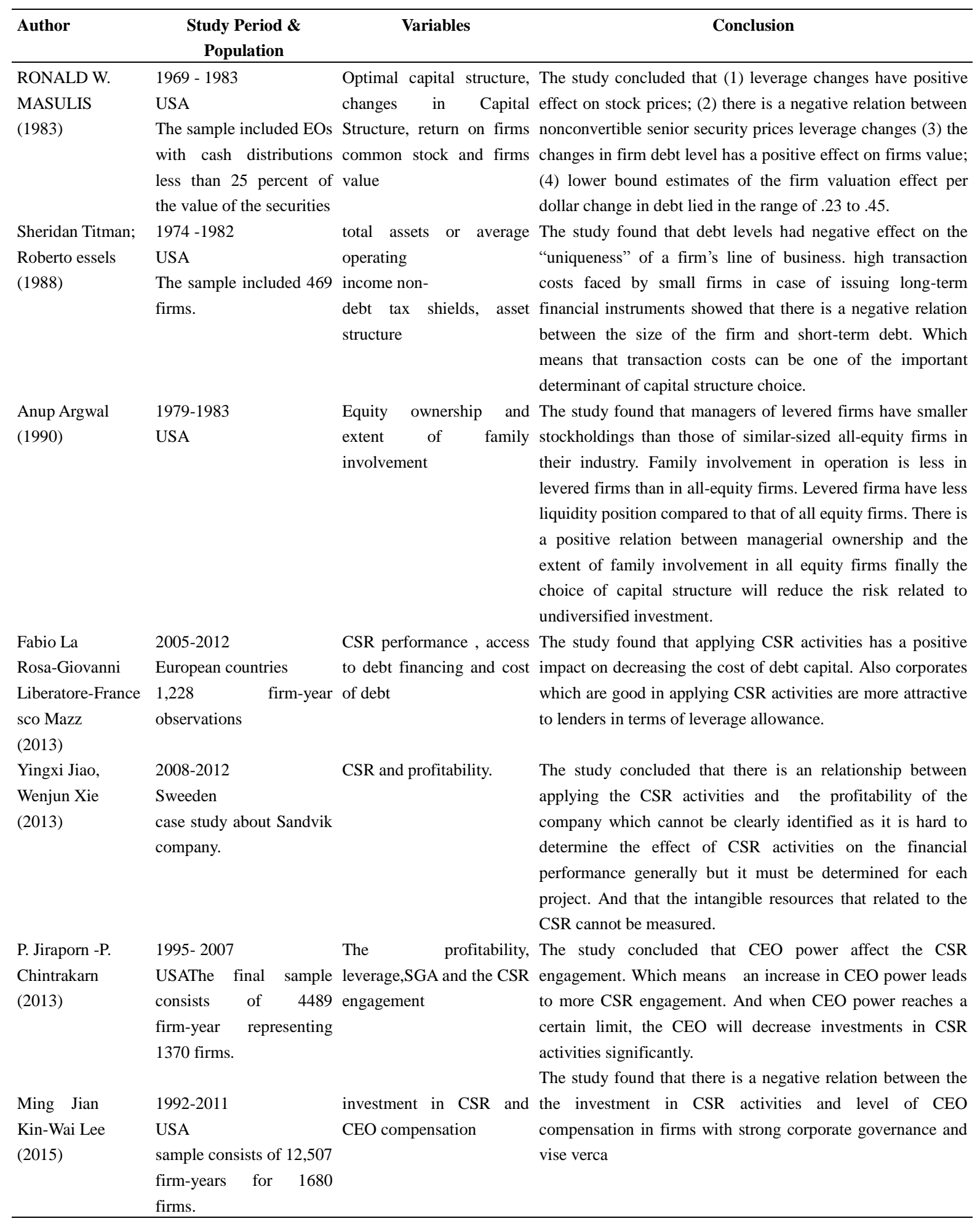




\begin{tabular}{lll}
\hline $\begin{array}{l}\text { Perinpanathan } \\
\text { Rajkumar(2014) }\end{array}$ & $\begin{array}{l}\text { 2006-2012 } \\
\text { Sri Lanka. } \\
\text { Case study e John Keells }\end{array}$ & Debt levels and financial \\
Holdings plc & $\begin{array}{l}\text { The study found that financial performance of John Keells } \\
\text { Holdings plc Sri Lanka was negatively affected by debt levels } \\
\text { during the periods of the study. However financial leverage }\end{array}$ \\
& & $\begin{array}{l}\text { has considerable impact on financial performance because the } \\
\text { amount of dividend paid decreased when debt level increased. }\end{array}$ \\
& Also there is a great negative interaction between return and \\
& volatility change in highly levered industries.
\end{tabular}

\begin{tabular}{|c|c|c|c|}
\hline $\begin{array}{l}\text { Nawaz Ahmad- } \\
\text { Atif Salman - } \\
\text { Aamir Firoz } \\
\text { Shamsi ( 2015) }\end{array}$ & $\begin{array}{l}2005-2010 \\
\text { Pakistan } \\
\text { Sample of } 18 \text { cement } \\
\text { companies }\end{array}$ & $\begin{array}{l}\text { fitability \& } \\
\text { ancial leverage }\end{array}$ & $\begin{array}{l}\text { The study concluded that profitability of corporates was } \\
\text { negatively affected by financial leverage of corporates in } \\
\text { cement manufacturing sector of Pakistan. }\end{array}$ \\
\hline Evgeny & $\begin{array}{l}2004-2013 \\
\text { Russia } \\
100,000 \text { firms } \\
\text { Bureau van } \begin{array}{l} \\
\text { Ruslana dataset }\end{array}\end{array}$ & $\begin{array}{l}\text { ROA, ROE, operating } \\
\text { margin and level of debt to } \\
\text { total asset }\end{array}$ & $\begin{array}{l}\text { The study concluded that the financial leverage has a negative } \\
\text { effect on ROA, ROE and operation margin.Corporate } \\
\text { performance is negatively affected by corporate indebtedness } \\
\text { this can be interpreted in the following ways: (1) inefficiency } \\
\text { of Russian market for corporate control; (2)obstacles in debt } \\
\text { attracting; (3) high growth potential of emerging markets; (4) } \\
\text { high interest rates of financing through debt; } \\
\text { (5) Transferring profits from the country to offshores; (6) an } \\
\text { insufficient clear budget limits for management. }\end{array}$ \\
\hline $\begin{array}{l}\text { Sanjoy Bose - } \\
\text { Robert W. McGee } \\
\text { - Sherine Farouk } \\
\text { Abdel All }\end{array}$ & $\begin{array}{l}2002-2010 . \\
\text { Saudi Arbia }\end{array}$ & $\begin{array}{l}\text { (Financial Leverage and } \\
\text { Zakat) } \\
\text { (ROA, ROE, GPM, NPM) }\end{array}$ & $\begin{array}{l}\text { Study found that there is an effect for capital structure on } \\
\text { capital performance in Saudi Arabian firms. Which means that } \\
\text { corporates with low leverage levels were found to have high } \\
\text { gross profit margins levels. }\end{array}$ \\
\hline
\end{tabular}

(2015)

Eric R. Brisker 2007-2013

Wei Wang USA

(2016)

1500 firms from the inside debt holding.

Standard \& Poor's

ExecuComp database.
The firm's capital structure The study concluded that the firm leverage has a negative and CEO's impact on the CEO's inside debt ratio, which calculated using pension plan and deferred compensation data. Also It was found that the CEO inside debt ratio is arround10\% of the corporates market debt ratio that will lead to optimal capital structure dynamics and that the offering debt-type compensation leads to decreasing managers' conservatism which will result in lower-than-optimal use of debt and slower capital structure adjustments toward shareholders' desired level, detrimental to shareholders' interests.

Fifi Swandari, Ali 2012

Sadikin Indonesia.

(2016) sample 64 companies

CSR, ownership structure, The study found CSR is affected by institutional ownership, profitability, leverage, firm managerial ownership, foreign ownership, profitability, size

capital structure.

$\begin{array}{lll}\text { He Feiying- Zou } & 2006-2014 & \text { capital structure. } \\ \text { Ziang (2016) } & \text { China } & \text { DCSR and CSR strength } \\ & \text { sample comprises 12,941 } & \\ & \text { samples of 1,208 firms } & \\ & \text { from china stock }\end{array}$

Khondkar Karim 1998-2012

CSR performance,

Eunju Lee, Sanghyun Suh USA

CEO compensation The sample consists of firms value 3000 publicly traded companies leverage and corporate size. Also it was concluded that CSR value will be decreased by debt level. The implementation of CSR programs will not be increased by firm size, CSR will be positively affected by ROE in case the corporate has enough funds to perform programs of CSR.CSR is negatively affected by leverage. as high debt level will focus more on dealing with the faced problems than investing in CSR

The study found that the issuing CSR statement reduces the rate of capital structure reconciliation, and that above-target leverage corporates that issue CSR statements have lower motives than below-target leverage corporates to return to the target leverage results showed that CSR statements improve long-term leverage but has no effect on short-term leverage.

the The study found that efficient CEO compensations structure is and associated with CSR activities practiced by the firm. And this will lead to higher firm value in case that the corporate formulate the CSR policies. 


\begin{tabular}{|c|c|c|c|}
\hline $\begin{array}{l}\text { Avishek Bhandari, } \\
\text { David Javakhadze } \\
\text { (2017) }\end{array}$ & $\begin{array}{l}1992 \text { to } 2014 \\
\text { USA } \\
\text { sample consists of an } \\
\text { unbalanced panel of } \\
15,670 \text { firm-year } \\
\text { observations }\end{array}$ & $\begin{array}{l}\text { CSR expenditure and } \\
\text { investment effeciency }\end{array}$ & $\begin{array}{l}\text { The study concluded that concentrating on CSR strategies } \\
\text { may inflict costs to a firm in the form of abstained investment } \\
\text { opportunities that in the long run is exhibited in the loss of } \\
\text { shareholder wealth. CSR had a negative effect on the } \\
\text { sensitivity of external finance to Q and aggravates investment } \\
\text { sensitivity to cash flow. } \\
\text { Plus, the deformation in The firm-level capital allocation } \\
\text { efficiency is reflected on the corporate performance. }\end{array}$ \\
\hline $\begin{array}{l}\text { Zhihong Wang } \\
\text { Joseph Sarkis } \\
\text { (2017) }\end{array}$ & $\begin{array}{l}2009-2013 \\
\text { USA } \\
\text { Sample used included } \\
1980 \text { usable firm-year } \\
\text { observations from } 423 \\
\text { companies. }\end{array}$ & $\begin{array}{l}\text { CSR outcomes, financial } \\
\text { performance indicators and } \\
\text { CSR governance, }\end{array}$ & $\begin{array}{l}\text { The study found that CSR outcomes fully propitiate the } \\
\text { relationship between CSR governance and financial } \\
\text { consequences which will be reflected in corporate financial } \\
\text { performance and this through using the four-step Baron and } \\
\text { Kenny approach. }\end{array}$ \\
\hline $\begin{array}{l}\text { J. Aloy Niresh \& } \\
\text { Dr. W. H. E. Silva } \\
(2018)\end{array}$ & $\begin{array}{l}\text { 2010-2014 } \\
\text { Sri Lanka }\end{array}$ & $\begin{array}{l}\text { CSR the financial } \\
\text { performance and the } \\
\text { leverage. }\end{array}$ & $\begin{array}{l}\text { The study found that there is a significant relation between } \\
\text { financial performance and CSRD when the financial } \\
\text { performance is measured in terms of ROE and ROA. Thus, it } \\
\text { can be concluded that CSRD is associated with better future } \\
\text { financial performance. CSR activities affect the economic } \\
\text { performance of companies and managers of should use CSR } \\
\text { as a mechanism to improve the performance of the } \\
\text { organization. So, companies can maximize its profit through } \\
\text { the application of managers to CSR practices. Sample }\end{array}$ \\
\hline
\end{tabular}

\section{Through Literature review, the study found the following:}

- There is an impact of applying CSR activities on firms value; both in global and emerging markets.

- Applying CSR activities, financial leverage and the financial performance of the corporate are related to each other and this will affect the corporate value.

- There is a correlation between CSR activities and the firms value.

- Applying CSR activities are affected by the firms size and the economic conditions of the country.

- The CSR and financial leverage are one of the determinants of investment in equity and government debt instruments.

\subsection{Study Problem}

In view of the adoption of the vision of Egypt 2030 for the plan of sustainable development, it was found that the institutions supervising the financial markets (the Egyptian Exchange) has announced the rules of registration written-off in 2014, which indicated the importance of the disclosure of the activities of corporate social responsibility and therefore the researcher chose to examine the effect of applying the activities of corporate social responsibility as well as the impact of financial leverage on the value of the most active companies listed in the Egyptian Stock Exchange in the period from 2104 to 2017. From literature review, the study found a research gap between the application of CSR activities, financial leverage together and expected corporate value of firms in Egypt, so the problem of the study is to identify to what extent CEO decisions regarding applying CSR activities and financial leverage can affect the performance of the Egyptian firms and this consequently will its corporate value.

\subsection{Study Hypotheses}

According to the study problem, the Study Hypotheses can be shown as follows:

- There is a significant impact of applying CSR activities on corporate value of Egyptian firms.

- The financial leverage and CSR can significantly affect the corporate value of firms registered in Egyptian common stock market.

- There is a significant relation between CSR and financial leverage together on corporate value.

\subsection{Study Objective}

The main objective of this study is to explain the relation between the CSR activities, financial leverage and their 
impact on the corporate value of companies registered in the Egyptian stock market.

\section{Corporate Social Responsibilities, Financial Leverage and Their Impact on the Corporate Value}

\subsection{CSR}

The idea of Corporate Social Responsibility (CSR) support the concept of doing business in a more human, ethical and more transparent way. CSR was identified as how corporates can run the business process to create a positive effect on the society and refers to serving people, communities, and the environment in ways that go above and beyond what is legally and financially required of a corporate." (Homework8) In Hong, Li,

Examples of CSR activities are as follows

1). Community involvement: Establishment and maintenance of roads. -Benefaction for the promotion of art, culture, and sports. -Providing drinking water facilities. -Granting healthcare programs. -building temples, community halls, parks, and so on.

2). Environmental Contribution: - Reprocessing of pollutants and wastes. - Engaged in eco-friendly products/ process. - Effectiveness in paper using. - Power saving/energy conservation.

3). Workplace: - Provision of better working environment to the employees. - Retirement fund benefit plans, i.e., gratuity, provident fund. - Conventional safety measures for accident-prone activities. - Continuous training/development programs for employees. - Expending on the welfare of employees. - Provision of medical facilities to employees. - Profit sharing/share ownership programs for employees.

4). Diverse: -No child labor in employment. -Miscellaneous training programs for enhancement of youth.

-Welfare activities for disabled persons. -Provision of agriculture guidance/schemes. -Financial inclusion schemes. -Constructing of orphanage home. -Better customer service/customer guidance/after sale service.

CSR is considered as a strategic and competitive program that can provide many welfare for the companies and societies. There are three causes why companies do CSR, namely: (1) concession, (2) reducing the risk and (3) producing value (Bhatt, 2002).

\subsection{Financial Leverage}

The level at which corporate make use of financial leverage is another factor that may enhance financial performance. According to Brigham and Gapenski (1997) "The extent to which a corporate uses debt financing". Financial leverage, has three important inferences: (1) By raising funds through borrowing funds, stockholders can control the corporate with a limited investment. (2) Creditors look to the owner-supplied funds, to provide an edge of safety, so if the stockholders have gave only a small proportion of the total financing, the risks of the corporate are borne mainly by its creditors. (3) If the corporate earns more on investments financed with debt than it pays in interest, the rate of return on owners' capital is increased, or leveraged. So corporates can use financial leverage as a tool that may improve financial performance.

The interrelation between CSR, financial leverage and the corporate value

Investment in CSR activities is accompanied by a greater corporate-specific focus on the benefits of other stakeholders (such as customers, owners, suppliers and employees), which increases shareholders' willingness to support a corporate's operation, which in turn increases shareholders' wealth. Thus applying CSR activities have a positive impact on shareholders' value. So it is anticipated that CEO will be recompesated for his effort in increasing investment in CSR activities.

Firms debt level or leverage have a negative effect on the CSR. It designates that firms with a high debt level will concentrate more on dealing with problem resulted from borrowing than investing in CSR activities. Finally, firm size has no effect on applying CSR activities. Which contradict the original assumption, it turns out to big firms do not always focus on applying CSR activities. Moreover, it is also proposed that the research can be applied in another sector with the aim that ownership structure will be proven to have a positive effect on CSR.

Corporate welfare from using debt is that payments of interest are not taxable and this may lead to improving corporate value. And this means that high indebtedness may lead to a better corporate performance. Many researches argued about whether there is positive or negative or neutral relation with firms value.

\section{Data and Methodology}

To retain the objectives of the study and testing the hypotheses the study use quantitative technique to measure effect of applying CSR activities and level of financial leverage on corporate value by determining the level of contribution of the company in CSR activities and the level of financial leverage by dividing the total owners' 
equity on the total assets and determining the value of the corporate by multiplying the number of shares by the market value of each share for each company.

The CSR rating criteria include strength and concern indicators for seven qualitative issue areas and six contentious business issue areas. The seven major qualitative issue areas include community, corporate governance, diversity, employee relations, environment, human rights, and product, and the six arguable business issues are alcohol, gambling, firearms, military, nuclear power, and tobacco and in the report of each firm from the field study there is a value for applying CSR activities.

\subsection{The Sample}

The data was collected from the most active companies registered in the CSR indicator in the Egyptian stock market during the period 2014-2017 the available data was for 17 companies from different sectors

The independent variables included the level of relying on debts in financing companies and the amount invested by firms in applying CSR activities and the dependent variable include the corporate value.

Inferential Statistical Methods Examine the effect of applying CSR activities and Financial leverage on corporate value

To measure the significant impact from CSR and Financial leverge on corporate value, using weighted least square; Table shows this output.

\begin{tabular}{|c|c|c|c|c|}
\hline \multicolumn{5}{|c|}{ Model 6: WLS, using 128 observations } \\
\hline \multicolumn{5}{|c|}{ Dependent variable: $\mathrm{CV}$} \\
\hline \multicolumn{5}{|c|}{ Heteroskedasticity-robust standard errors, variant $\mathrm{HC} 1$} \\
\hline \multicolumn{5}{|c|}{ Variable used as weight: const } \\
\hline & coefficient & std. error & $\mathrm{z}$ & p-value \\
\hline const & $9.41052 \mathrm{e}+08$ & $1.48006 \mathrm{e}+09$ & 0.6358 & 0.5249 \\
\hline SR & -0.447946 & 0.439790 & -1.019 & 0.3084 \\
\hline FL & $1.09239 \mathrm{e}+08$ & $4.57541 \mathrm{e}+07$ & 2.388 & $0.0170^{* *}$ \\
\hline \multicolumn{5}{|c|}{ Warning: data matrix close to singularity! } \\
\hline \multicolumn{5}{|c|}{ Statistics based on the weighted data: } \\
\hline Sum squared resid & $4.85 \mathrm{e}+21$ & S.E. of regression & & $6.23 e+09$ \\
\hline R-squared & 0.149403 & Adjusted R-squared & & 0.135793 \\
\hline $\mathrm{F}(2,125)$ & 10.97778 & P-value(F) & & 0.000041 \\
\hline Log-likelihood & -3066.888 & Akaike criterion & & 6139.776 \\
\hline Schwarz criterion & 6148.332 & Hannan-Quinn & & 6143.252 \\
\hline \multicolumn{5}{|c|}{ Statistics based on the original data: } \\
\hline Mean dependent var & $5.38 \mathrm{e}+09$ & S.D. dependent var & & $6.70 \mathrm{e}+09$ \\
\hline Sum squared resid & $4.85 \mathrm{e}+21$ & S.E. of regression & & $6.23 e+09$ \\
\hline
\end{tabular}

From the previous table:

It is clear that there is a significant effect for the financial leverage while there is an insignificant effect for the investment in CSR activities on the corporate value of the Egyptian companies. The researcher reached to this result from testing all the companies registered in social corporate responsibility in the Egyptian stock market. The results of the previous table showed that about $13.58 \%$ of the change in the corporate value of the Egyptian companies were affected by the independent variable (financial leverage and the corporate social responsibility).These results were interpreted based on the volatility of the local interest rates between $9 \%$ and $20 \%$ beside the low level of awareness of the investors in the Egyptian stock market about the importance of applying the activities of the social corporate responsibility.

\section{Conclusion and Recommendation}

From the previous studies some of them test the relation between CSR and Financial leverage, other investigate the relation financial leverage and corporate value and the relation between CSR and the firms value and none of them test the effect of both CSR and financial leverage on the corporate value at same paper, that's why the researcher test the effect of both variables on the corporate value. The results of the study showed that in the Egyptian market there is an effect for financial leverage on the corporate value while there is no significant effect for applying CSR activities on the corporate value which support the idea of lack of awareness by investors in 
the Egyptian stock market about the importance of applying the activities of CSR. The conclusion is considered as a continuity for the results of the previous studies as (Ronald, 1983) found a positive relation stock prices and leverage changes, (Sheridan, 1988) concluded a negative relation between debt levels and transaction costs of the firm, (Perinpanathan, 2014) found a negative impact of financial leverage on financial performance of John Keels. (Nawaz, 2015) concluded a negative relation between financial leverage and profitability also (Ilyukin, 2015) found that financial leverage negatively affect ROA and ROE. (Sanjoy, 2015) found a negative effect of financial leverage on gross profit margin. Other studies highlighted the relation between CSR and financial leverage like the study of (Fbio, 2013) who concluded that CSR had an appositive effect on the cost of debt. (Fifi, 2016) found a negative relation between applying the activities of CSR and the leverage of the firm on the other side there are other studies supported the idea that there is a relation between the firms value and the CSR like (Yingix, 2013) who concluded that applying CSR activities affect the performance of the firm. (Kandhar, 2107) found that practicing CSR activities will lead to higher firm value. (Avishek, 2017) and (Zhihong, 2017) concluded that CSR affect the firm performance.

J.Aloy Niresh found that CSR can be used as a tool for enhancing organizations performance and this will lead to maximizing profit. So the study recommended the activation of the role of professional associations and carrying out conferences and seminars as a tool for enhancing the awareness of investors about the importance of applying CSR activities which is one of the requirements for achieving the development estability to fit the vision of future development by year 2030 .

\section{References}

Anne, E. F., Guy, M. R., \& John, V. L. (2017). Developing community based models of Corporate Social Responsibility. The Extractive Industries and Society, 5(1), 131-143.

Anup, A. (1990). Corporate capital structure, Agency cost and ownership control: The case of all equity firms. The Journal of Finance, (4), 1325-1331. https://doi.org/10.1111/j.1540-6261.1990.tb02441.x

Dwi, K., \& Marisa, M. (2016). The Effect of Leverage and Firm Size to Profitability of Public Manufacturing Companies in Indonesia. International Journal of Economics and Financial Issues, 6(2), 409-413. Retrieved from https://ssrn.com/abstract=2769118

Eric, R. B., \& Wei, W. (2016). CEO's Inside Debt and Dynamics of Capital Structure. Review of Financial Economics, 46(3), 655-685. https://doi.org/10.1111/fima.12169

Fabio, L. R., Giovanni, L., Francesco, M., \& Simone, T. (2018). The impact of corporate social performance on the cost of debt and access to debt financing for listed European non-financial firms. European Management Journal, 36(4), 519-529. https://doi.org/10.1016/j.emj.2017.09.007

Fifi, S., \& Ali, S. (2016). The Effect of ownership structure, profitability, leverage, and firm size on corporate social responsability (CSR). Binus Business Review, 7(3), 315-320. https://doi.org/10.21512/bbr.v7i3.1792

Ilyukhin, E. (2015). The Impact of financial leverage on firm performance: Evidence from Russia. Journal of $\begin{array}{lllll}\text { Corporate } \quad \text { Finance, 24-36. } & \text { 2, } & \text { Retrieved }\end{array}$ https://cyberleninka.ru/article/n/the-impact-of-financial-leverage-on-firm-performance-evidence-from-russi a.

Joseph, M. P., \& Wenbin, S. (2017). Doing good and doing bad: The impact of corporate social responsibility and irresponsibility on firm performance. Journal of Business Research, 80, 82-97. https://doi.org/10.1016/j.jbusres.2017.07.007

Kee-Hong, B., Sadok, El G., Omrane, G., Chuck, C. Y. K., \& Ying, Z. (2017). Does Corporate Social Responsibility Reduce the Costs of High Leverage? Evidence from Capital Structure and Product Markets Interactions. Journal of Banking and Finance, Forthcoming. http://dx.doi.org/10.2139/ssrn.2959444

Khalaf, T. (2012). Impact of Working Capital Management Policy and Financial Leverage on Financial Performance: Empirical evidence from Amman Stock Exchange - listed companies. International Journal of Management Sciences and Business Research, 1(8), 10-17. Retrieved from https://ssrn.com/abstract=2702233

Khondkar, K., Eunju, L., \& Sanghyun, S. (2018). Corporate social responsibility and CEO compensation structure. Advances in Accounting Journal, 40, 27-41. https://doi.org/10.1016/j.adiac.2017.11.002

Meng, Z. (2015). CEO Power and Corporate Social Responsibility. https://doi.org/10.2139/ssrn.2594953

Ming, J., \& Kin-Wai, L. (2015). CEO compensation and corporate social responsibility. J. of Multi. Fin. Manag., 
29, 46-65. https://doi.org/10.1016/j.mulfin.2014.11.004.

Nawaz, A., Atif, S., \& Aamir, F. S. (2015). Impact of Financial Leverage on Firms' Profitability: An Investigation from Cement Sector of Pakistan. Journal of Finance and Accounting, 6(7), 78-81. Retrieved from https://ssrn.com/abstract=2603248

Perinpanathan, R. (2014). Impact of Financial Leverage on Financial Performance: Special Reference to John Keells Holdings plc in Sri Lanka. Scientific Research Journal (SCIRJ), II(II). http://dx.doi.org/10.2139/ssrn.2720276.

Pradeep, K. (2017). Relationship between degree of financial leverage and earning per share. International Journal of Research in Business Management, 5(11), 5-10. Retrieved from https://ssrn.com/abstract=3090960

Ronald, W., \& Masulis. (1983). The Impact of Capital Structure Change on Firm Value: Some Estimates. The Journal of Finance, 38(1), 107-126. https://doi.org/10.1111/j.1540-6261.1983.tb03629.x

Saiqa, Y. (2017). Impact of Financial Leverage on Firm's Performance - A Case of Cement Production Industries of Pakistan. International Journal of Management Sciences and Business Research, 6, 98-105 Retrieved from https://ssrn.com/abstract=2912754.

Shafat, M., \& M. Nasir, Z. (2018). Corporate social responsibility and financial performance: An empirical analysis of Indian banks. Future Business Journal, 4, 84-93. https://doi.org/10.1016/j.fbj.2017.12.002

Shahal, S., Imran, R. M., Mukhtar, A., \& Mukhtiar, A. (2016). Does Corporate Social Responsibility Improve The Firm's Financial Performance: A Theoretical Prespective of Agency and Stakeholder Theory by Financial Sector of Pakistan. Journal of Contemporary Management Sciences, 3(II), 137-156. Retrieved from https://ssrn.com/abstract=3105343 .

Shenggang, Y., Qi, Z., Feiying, H., \& Ziang, Z. (2018). How Does Corporate Social Responsibility Change Capital Structure? Asia-Pacific Journal of Accounting \& Economics, 25(3-4), 352-387. https://doi.org/10.1080/16081625.2017.1354710

Sheridan, T., \& Roberto, W. (1988). The Determinants of Capital Structure Choice. The Journal of Finance, 43(1), 1-19. https://doi.org/10.1111/j.1540-6261.1988.tb02585.x

\section{Copyrights}

Copyright for this article is retained by the author(s), with first publication rights granted to the journal.

This is an open-access article distributed under the terms and conditions of the Creative Commons Attribution license (http://creativecommons.org/licenses/by/4.0/). 